\title{
MENGKAJI PERBEDAAN KEMAMPUAN MATEMATIS SISWA MENGGUNAKAN MODEL PEMBELAJARAN KOOPERATIF THINK PAIR SHARE (TPS) DAN MODEL PEMBELAJARAN KONVENSIONAL DI KELAS VIII SMP DITINJAU DARI LEVEL SEKOLAH
}

\author{
Assessing the Difference of Mathematical Capability Students Using Cooperative \\ Learning Think Pair Share (TPS) Model and Conventional Learning Model in Class \\ VIII SMPReviewed from School Levels
}

\author{
Anderson L. Palinussa ${ }^{1 *}$, Abdulla Thaib ${ }^{2}$ \\ ${ }^{1,2}$ Program Studi Pendidikan Matematika, Fakultas KIP, Universitas Pattimura \\ Jln. Ir. M. Putuhena Kampus Unpatti, Poka-Ambon,97233, Indonesia \\ e-mail: ${ }^{*}$ apalinussa@yahoo.com; ${ }^{2}$ thaibabdulla@gmail.com \\ Corresponding author*
}

\begin{abstract}
Abstrak
Tujuan penelitian ini untuk mengkaji perbedaan kemampuan matematis siswa untuk sekolah dengan akreditasi sedang dan akreditasi rendah ketika diberikan perlakuan yang sama dengan menerapkan model pembelajaran kooperatif think pair share (TPS) yang dibandingkan dengan model pembalajaran konvensional dalam hal ini pada materi lingkaran. Populasi dalam penelitian ini adalah seluruh siswa kelas VIII SMP di sekolah berakreditasi sedang dan akreditasi rendah di kota Ambon. Sampel dari penelitian ini yaitu siswa kelas VIII SMP AL-Wathan Ambon dengan akreditasi sedang dan siswa kelas VIII SMP ASSSalam Ambon dengan akreditasi rendah. Tipe penelitian yang digunakan adalah tipe penelitian eksperimental (Experimental Research). Dengan desain penelitiannya adalah Post test Only Control Group Design. Hasil eksperimen untuk kedua sekolah menunjukkan nilai Sig. (2-tailed) kurang dari nilai alfha yakni $0,012<0,05$ sehingga menyebabkan $\mathrm{H}_{0}$ ditolak dan $\mathrm{H}_{1}$ diterima yang berarti ada perbedaan kemampuan matematis siswa kelas VIII SMP menggunakan model pembelajaran kooperatif hink pair share dan model pembelajaran konvensional ditinjau dari level sekolah.
\end{abstract}

Kata Kunci: Kemampuan matematis, Think Pair Share (TPS), konvensional

\begin{abstract}
The purpose of this research is to study the differences in students' mathematical abilities of schools with middle accreditation level and low accreditation level when given the same treatment by applying Think Pair Share (TPS) model compared to conventional models on the circle concept. The Population of this research is schools with a midddle accreditation level and low accreditation level in Ambon. Samples of this research are students on the $8^{\text {th }}$ grade of SMP Al-Wathan Ambon which has middle accreditation level and students on $8^{\text {th }}$ grade of SMP Ass Salam Ambon which has low-level accreditation. This research is experimental research by using Post Test Only Control Group Design. The results on these schools shown that a significant value less than alpha value, in precisely $0,012<0,05$, which means $H_{0}$ is rejected and $H_{1}$ is accepted. This statistical expression means that there is a difference in students' mathematical abilities through the application of Think Pair Share and Conventional model reviewed from school levels.
\end{abstract}

Keywords: Mathematical abilities, Think Pair Share (TPS), conventional. 


\section{PENDAHULUAN}

Pendidikan memegang peranan penting dalam menghadapi tantangan zaman serta perkembangan sains dan teknologi. Berbagai upaya dilakukan oleh pemerintah untuk mencerdaskan anak bangsa salah satunya dengan proses pembelajaran di sekolah. Selain itu pemerintah juga meningkatkan perbaikan mutu pendidikan yaitu dengan pembaharuan kurikulum untuk meningkatkan potensi siswa dalam memaksimalkan proses belajar mengajar. Salah satu ilmu yang berperan penting dalam kehidupan adalah matematika. Matematika sebagai salah satu ilmu dasar, baik aspek terapannya maupun aspek penalarannya, sangat berperan penting dalam pengusaan ilmu pengetahuan dan teknologi, oleh karena itu penguasaan dan pemahaman ilmu matematika dari siswa perlu ditingkatkan mulai dari tingkat sekolah dasar hingga ke perguruan tinggi [6].

Matematika perlu diberikan kepada semua siswa mulai dari tingkatan yang paling mendasar yaitu siswa sekolah dasar untuk membekali para siswa dengan kemampuan berpikir logis, kritis, sistematis, analitis dan kreatif dan serta kemampuan bekerja sama. Kompetensi tersebut sangat diperlukan agar siswa dapat memiliki kemampuan memperoleh, mengelola, dan memanfaatkan informasi yang ada untuk bertahan hidup pada keadaan sesuai dengan perkembangan ilmu dan teknologi yang selalu berubah, tidak pasti, dan kompetitif. Jika para siswa mempunyai kemampuan bernalar secara logis, analitis dan kritis maka siswa-siswa cenderung akan lebih mudah dalam memahami konsep dan memecahkan masalah matematika serta mengkomunikasikan gagasannya. Hal ini berpengaruh pada hasil belajar matematika siswa di sekolah [2].

Belajar matematika dianggap sangat penting bagi setiap orang di dunia. Siswa diminta untuk belajar matematika yang dianggap sebagai pendidikan dasar, karena keterampilan perhitungan matematika sangat penting dalam setiap langkah kehidupan. Namun perkembangan pembelajaran matematika di Indonesia khususnya di Maluku masih jauh dari harapan. Praktek pembelajaran matematika di kelas masih berpusat pada guru. Guru menyampaikan pelajaran menggunakan metode ceramah atau konvensional dan para siswa hanya mencatatnya pada buku catatan. Selain itu kebanyakan siswa di sekolah yang beranggapan bahwa belajar matematika itu tidak menyenangkan dan hanya menjadi rutinitas tanpa diiringi dengan kesadaran untuk menambah wawasan mereka tentang matematika. Padahal matematika itu sendiri sangat berguna dalam kehidupan sehari-hari [8].

Menyadari pentingnya peranan matematika, maka sekolah mempunyai kontribusi yang sangat besar dalam hal tersebut melalui pembelajaran matematika di kelas. Mata pelajaran matematika yang diajarkan di sekolah-sekolah harus dirancang tidak hanya untuk mempersiapkan para siswa melanjutkan study ke pendidikan yang lebih tinggi tetapi juga untuk menghadapi tantangan di era revolusi industri. Dalam proses belajar mengajar, seorang guru harus mempelajari banyak pendekatan dalam pengajaran dan juga model-model pembelajaran yang inovasi. Dengan menguasai pendekatan pengajaran dan model pembelajaran yang banyak, proses belajar dan mengajar di kelas dapat berjalan secara variatif, aktif, tidak monoton dan selalu menyenangkan. Dengan demikian guru harus melakukan evaluasi rutin tentang efektivitas model maupun pendekatan yang digunakan dalam pembelajaran di kelas [1]. Namun sampai saat ini sebagian besar siswa merasa bosan, tidak tertarik dan bahkan benci terhadap matematika. Matematika masih menjadi pelajaran yang menakutkan bagi sebagian siswa. Selain pembelajaran yang dilakukan di sekolah-sekolah selama ini masih bersifat klasikal yaitu guru terlalu mendominasi sehingga keterlibatan siswa dalam proses pembelajaran sangat kurang. Hal senada juga disampaikan oleh [11] bahwa pembelajaran matematika saat ini kurang memberikan perhatian pada aktivitas siswa. Guru mendominasi selama kegiatan belajar mengajar, sehingga guru ditempatkan sebagai sumber utama pengetahuan dan berfungsi sebagai pentransfer pengetahuan. Sebaliknya siswa lebih banyak pasif, tidak berani menyampaikan ide-ide, mereka diposisikan hanya sebagai objek belajar, dikondisikan hanya untuk menunggu proses transformasi pengetahuan dari guru sehingga guru lebih mendominasi kelas dan siswa lebih cenderung menerima, akibat proses pembelajaran menjadi tidak bermakna dan bersikap negatif terhadap matematika. Praktek pembelajaran seperti ini yang menjadi salah satu penyebab hasil belajar matematika siswa dari tahun ke tahun belum memperlihatkan hasil yang memuaskan.

Menurut [9] terdapat beberapa faktor yang menyebabkan hasil belajar siswa menjadi rendah yaitu: 1. Pembelajaran matematika masih berpusat pada guru, selama pembelajaran berlangsung tidak ada interaksi antara guru dan siswa, guru terlalu mendominasi sedangkan siswa hanya menerima pengetahuan yang disampaikan oleh guru dan mencatatnya di buku catatan.

2. Tidak adanya keterlibatan siswa dalam proses pembelajaran, selama proses pembelajaran berlangsung guru tidak melibatkan siswa baik untuk bertanya ataupun mengeluarkan pendapatnya.

3. Guru kurang kreatif untuk mengkondisikan para siswa selama proses pembelajaran, sehingga siswa masih banyak yang ribut dan tidak memperhatikan apa yang dijelaskan oleh guru. 
4. Rendahnya keinginan siswa untuk dapat berbagi pengetahuan dengan siswa yang lain sehingga pengetahuan yang dimiliknya tidak berkembang.

Untuk menjawab permasalahan tersebut salah satunya menggunakan model pembelajaran yang dapat memperbaiki dan meningkatkan mutu proses belajar mengajar. Salah satu alternatif model pembelajaran yang dapat diterapkan dalam proses pembelajaran adalah model pembelajaran kooperatif. [3] menyatakan bahwa dalam proses pembelajaran siswa harus terlibat aktif dan menjadi pusat kegiatan pembelajaran di kelas. Pada model pembelajaran kooperatif, kesempatan diberikan pada siswa untuk mengkonstruksikan pengetahuannya sendiri, berkomunikasi dan berinteraksi dengan teman kelompoknya untuk mencapai tujuan pembelajaran. Sementara guru hanya berperan sebagai motivator dan fasilitator aktivitas siswa. Selain itu, menurut [14] pembelajaran kooperatif (cooperative learning) merupakan kumpulan strategi yang dirancang agar siswa dapat bekerjasama dalam kelompok sehingga terjadinya interaksi antar siswa selama proses pembelajaran. Pembelajaran kooperatif, dapat mengembangkan keterampilan dan pemahaman siswa untuk bekerjasama serta mampu untuk mencapai keberhasilan suatu tujuan.

Salah satu model pembelajaran kooperatif yang mengutamakan kerjasama, efektif dan mudah diterapkan adalah model pembelajaran kooperatif Think Pair Share (TPS) yang dikembangkan oleh Frank Lyman dan kawan-kawan pada tahun 1985 dari Universitas Maryland.TPS merupakan salah satu model pembelajaran kooperatif yang memberi kesempatan pada siswa untuk bekerja sendiri serta bekerja sama dengan orang lain. Keunggulan dari model pembelajaran ini, yaitu mampu mengoptimalkan partisipasi siswa [15]. Selain itu Menurut [13] TPS dalah jenis pembelajaran kooperatif yang dirancang untuk mempengaruhi pola interaksi siswa. Model Pembelajaran kooperatif TPS dirancang agar siswa terlatih berkomunikasi untuk mengungkapkan berbagai ide yang ada di pikirannya selama proses pembelajaran, baik kepada guru maupun temannya. Hal ini dapat dilihat dari tahap-tahap pembelajaran TPS yaitu berpikir, berpasangan, dan berbagi.

Adapun manfaat dari penerapan model pembelajaran TPS adalah: 1) memungkinkan siswa bekerja sendiri dan bekerja sama dengan orang lain; 2) mengoptimalkan partisipasi siswa; dan 3) siswa diberi kesempatan untuk menunjukkan partisipasi mereka kepada orang lain. Langkah-langkah dalam model pembelajaran TPS aitu 1) siswa ditempatkan dalam kelompok-kelompok. Setiap kelompok terdiri dari 4 anggota/siswa; 2) tugas diberikan oleh guru untuk semua kelompok; 3) setiap anggota memikirkan dan mengerjakan tugas secara individu terlebih dahulu; 4) kelompok membentuk anggota-anggotanya secara berpasangan. Kemudian setiap pasangan mendiskusikan hasil pekerjaan individunya; dan 5) kedua pasangan lalu bertemu kembali dalam kelompoknya masing-masing untuk men-share hasil diskusinya [4].

Berdasarkan uraian yang dikemukakan di atas, maka yang menjadi tujuan dalam penelitian ini adalah untuk mengetahui apakah ada perbedaan kemampuan matematis siswa menggunakan model pembelajaran kooperatif TPS dan model pembelajaran konvensional di kelas VIII SMP ditinjau dari level sekolah.

\section{METODE PENELITIAN}

Penelitian ini dilaksanakan di dua sekolah yaitu SMP AL-Wathan Ambon dengan akreditasi sekolah sedang dan SMP ASS-Salam Ambon dengan akreditasi sekolah rendah. Tipe yang digunakan dalam penelitian ini adalah tipe penelitian eksperimental (Experimental Research)[12]. Penelitian dilaksanakan di kelas VIII dari kedua sekolah tersebut. Pada penelitian ini menggunakan dua kelas dari masing-masing sekolah, satu kelas sebagai kelas eksperimen dan satu kelas lainnya sebagai kelas kontrol. Pada kelas eksperimen diajarkan menggunakan model pembelajaran TPS dan kelas kontrol diajarkan dengan model pembelajaran konvensional.

Penelitian ini terdiri dari dua variabel yaitu variabel bebas (model pembelajaran) dan variabel terikat (kemampuan matematis dalam hal ini hasil belajar siswa). Populasinya adalah seluruh siswa kelas VIII SMP AL-Wathan dan SMP ASS-Salam Ambon. Teknik pengambilan sampel menggunakan teknik random. Teknik pengumpulan data menggunakan teknik tes. Tes hasil belajar digunakan untuk pengambilan data posttest siswa di kelas eksperimen maupun kelas kontrol. Teknik analisis data menggunakan uji beda ratarata atau uji-t untuk menguji hipotesis. Sebelum menggunakan uji-t terlebih dahulu digunakan uji normalitas dan uji homogenitas. 


\section{HASIL dan PEMBAHASAN}

\subsection{Hasil}

Data kuantitatif pada penelitian ini diperoleh dari hasil tes kemampuan matematika data diperoleh dari 108 siswa, terdiri dari 54 siswa yang memperoleh pembelajaran dengan model TPS (kelas eksperimen) dan 54 siswa yang memperoleh pembelajaran dengan model pembelajaran konvensional (kelas kontrol). Para siswa tersebut berasal dari sekolah level sedang dan level rendah berdasarkan pada Penilaian Acuan Patokan (PAP). Adapun nilai rata-rata dan distribusi sampel penelitian disajikan pada Gambar 1, Gambar 2, dan Tabel 1 berikut:
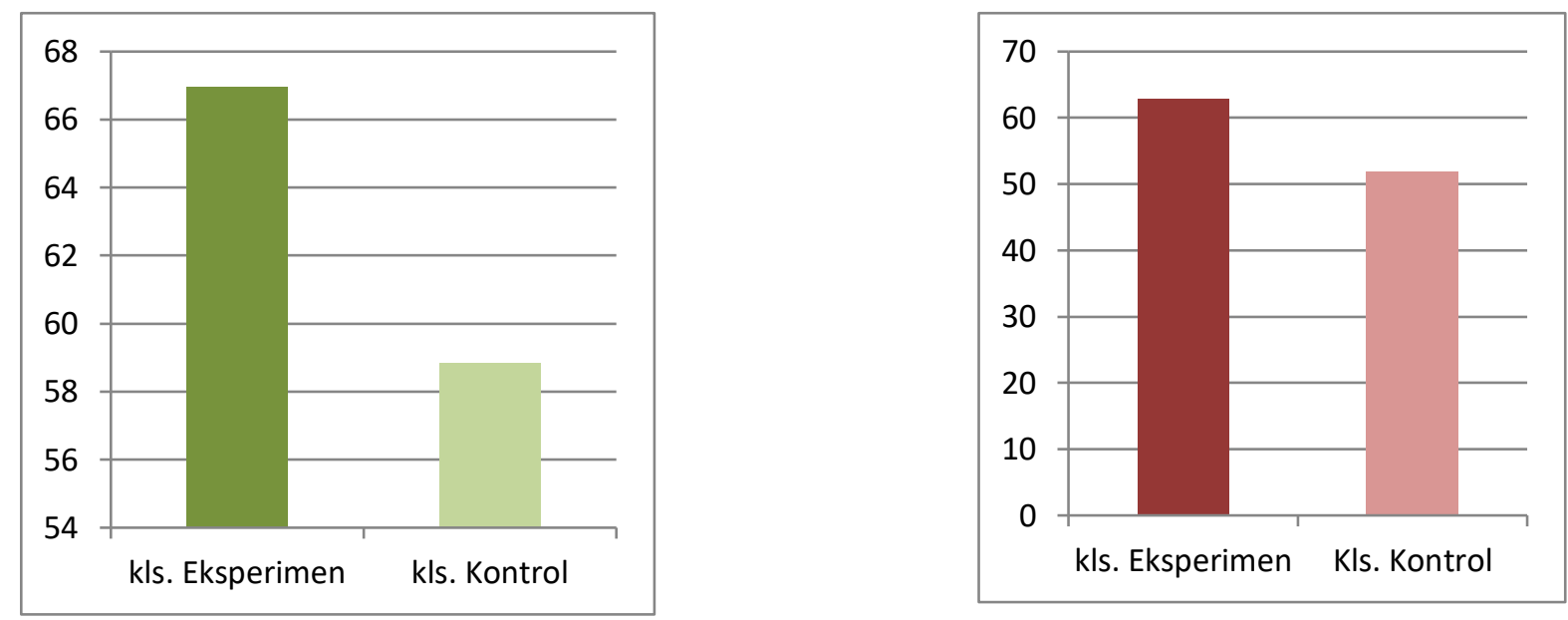

Gambar 1. Nilai Rata-Rata Sekolah Level Sedang Gambar 2. Nilai Rata-Rata Sekolah Level Rendah

Tabel 1. Distribusi Sampel Penelitian

\begin{tabular}{|ccccccc|}
\hline & \multicolumn{3}{c}{$\begin{array}{c}\text { Kelas Eksperimen } \\
\text { (RME) }\end{array}$} & \multicolumn{3}{c|}{$\begin{array}{c}\text { Kelas Kontrol } \\
\text { (Konvensional) }\end{array}$} \\
\cline { 2 - 7 } PAM & $\begin{array}{c}\text { Sekolah } \\
\text { Sedang }\end{array}$ & $\begin{array}{c}\text { Sekolah } \\
\text { Rendah }\end{array}$ & Jumlah & $\begin{array}{c}\text { Sekolah } \\
\text { Sedang }\end{array}$ & $\begin{array}{c}\text { Sekolah } \\
\text { Rendah }\end{array}$ & Jumlah \\
\cline { 2 - 7 } Rendah & $\mathbf{2}$ & $\mathbf{8}$ & $\mathbf{1 0}$ & $\mathbf{1 2}$ & $\mathbf{1 2}$ & $\mathbf{2 4}$ \\
Sedang & $\mathbf{2 1}$ & $\mathbf{1 6}$ & $\mathbf{3 7}$ & $\mathbf{1 2}$ & $\mathbf{1 3}$ & $\mathbf{2 5}$ \\
Tinggi & $\mathbf{4}$ & $\mathbf{3}$ & $\mathbf{7}$ & $\mathbf{3}$ & $\mathbf{2}$ & $\mathbf{5}$ \\
Total & $\mathbf{2 7}$ & $\mathbf{2 7}$ & $\mathbf{5 4}$ & $\mathbf{2 7}$ & $\mathbf{2 7}$ & $\mathbf{5 4}$ \\
\hline
\end{tabular}

Analisis statistik yang digunakan untuk menganalisis data kemampuan matematika adalah Uji t. Tetapi sebelumnya terlebih dahulu diuji normalitas dan homogenitas data dari masing-masing kelompok. Untuk uji normalitas distribusi data, digunakan uji Kolmogorov-Smirnov. Sedangkan uji homogenitas varians populasi, digunakan uji Fisher.

Untuk mengetahui sampel yang digunakan normal atau tidak, maka dilakukan perhitungan uji normalitas dengan menggunakan uji Kolmogorov-Smirnov dan diperoleh hasil pada Tabel 2 berikut ini.

Tabel 2. Hasil Uji Normalitas

\begin{tabular}{|cccc|}
\hline Kelas & Sig. & $\boldsymbol{\alpha}$ & Kesimpulan \\
\hline Eksperimen & 0,009 & 0,05 & Terima $\mathrm{H}_{1}$ \\
Kontrol & 0,200 & 0,05 & Terima $\mathrm{H}_{0}$ \\
\hline
\end{tabular}

Dari tabel di atas terlihat bahwa pada kelas eksperimen, diperoleh nilai Sig. lebih kecil dari nilai $\alpha$ $=0,05$ yaitu 0,009 hal ini berarti bahwa $\mathrm{H}_{1}$ diterima. Sedangkan pada kelas kontrol, nilai Sig. lebih besar dari nilai $\alpha=0,05$ yaitu 0,200 . Hal ini berarti bahwa $\mathrm{H}_{1}$ ditolak dan $\mathrm{H}_{0}$ diterima. Dengan demikian dapat disimpulkan bahwa data penelitian yang diambil untuk kedua kelas adalah tidak berdistribusi normal.

Setelah uji normalitas yang hasilnya ternyata data tidak berdistribusi normal, maka dilakukan uji Mann-Whitney, seperti pada Tabel 3 berikut. 
Tabel 3. Uji Mann-Whitney Tes Kemampuan Matematis

\begin{tabular}{|c|c|c|c|}
\hline & Sig. & $\boldsymbol{\alpha}$ & Kesimpulan \\
\hline $\begin{array}{c}\text { Post tes } \\
\text { Kemampuan Matematis }\end{array}$ & 0.012 & 0,05 & Tolok $\mathrm{H}_{0}$ \\
\hline
\end{tabular}

Tabel diatas menunjukkan bahwa hasil uji Mann-Whitney terhadap post tes kemampuan matematis berdasarkan hasil belajar siswa memiliki nilai sig. lebih kecil dari 0.05. Dengan demikian hipotesis nol ditolak. Artinya, ada perbedaan yang signifikan kemampuan matematis berdasarkan tes hasil belajar siswa.

\subsection{Pembahasan}

Dari hasil penelitian dengan memberikan perlakuan kepada kedua kelas di masing-masing sekolah dengan kelas eksperimen menggunakan model pembelajaran TPS dan kelas kontrol menggunakan model pembelajaran konvensional. Dari nilai rata-rata tes hasil belajar untuk kedua sekolah terlihat bahwa kelas kontrol memiliki nilai yang lebih rendah dari pada kelas eksperimen hal tersebut menunjukkan bahwa kelas eksperimen dengan menerapkan model pembelajaran TPS ebih baik jika dibandingkan dengan kelas control yang menerapkan model pembelajaran konvensional.

Model pembelajaran kooperatif TPS lebih baik dari model pembelajaran konvensional karena dalam model pembelajaran kooperatif TPS melibatkan siswa secara aktif melalui tahap think (berpikir), pair (berpasangan), dan share (berbagi) sehingga adanya interaksi yang baik antara siswa dengan guru, maupun antara siswa dengan siswa lainnya. Menurut [5], model pembelajaran kooperatif TPS ini memberi siswa waktu untuk berpikir dan merespons serta saling bantu satu sama lain.

Pada kegiatan inti pembelajaran, pertama guru melakukan demonstrasi untuk menggali pengetahuan awal siswa dengan tanya jawab selama 2 menit dan siswa memikirkan dan mengerjakan jawabannya secara individu terhadap pertanyaan yang diberikan. Selanjutnya guru membagikan lembar kerja siswa (LKS) kepada masing-masing siswa dan meminta siswa untuk mengerjakan masalah yang ada pada LKS secara individu. Pada tahap think, masing-masing siswa berpikir masalah yang diberikan dalam bentuk LKS secara individu sebelum mereka berdiskusi dengan pasangannya. Pada tahap tersebut siswa terlihat aktif untuk mencari solusi dari tugas atau masalah yang diberikan secara individu sehingga mereka dapat berdiskusi dengan pasangannya mengenai solusi dari masalah yang diberikan dalam LKS. Setelah itu guru membentuk siswa dalam kelompok-kelompok secara berpasangan dengan memperhatikan kemampuan siswa secara heterogen. Pada tahap pair, setiap kelompok mendiskusikan mengenai jawaban atas permasalahan yang diberikan pada LKS. Setiap pasangan terlihat saling membantu dalam menyelesaikan LKS dan menjelaskan materi yang tidak dipahami teman kelompoknya, hal tersebut membuat mereka dapat bekerja sama, saling berpendapat, dan dapat menerima pendapat orang lain. Setelah menyelesaikan masalah yang ada pada LKS, dilanjutkan dengan tahap share, yaitu guru meminta salah satu perwakilan dari kelompok untuk mempresentasikan jawaban mereka di depan kelas dan kelompok lain juga diberi kesempatan untuk menanggapi atau memberi masukan terhadap kelompok yang presentasi. Bagi kelompok yang mempresentasikan atau yang menanggapi diberikan penghargaan berupa pujian dan tepuk tangan dari guru dan teman-temannya, sehingga siswa lebih bersemangat dalam menyelesaikan LKS pada pembelajaranpembelajaran selanjutnya. Pada akhir pembelajaran guru bersama-sama dengan siswa menyimpulkan materi yang telah dipelajari.

Pada kelas kontrol yang diajarkan menggunakan model pembelajaran konvensional, pada awalnya guru menyampaikan materi yang akan dipelajari dan menyampaikan tujuan pembelajaran. Setelah itu, selama proses pembelajaran berlangsung guru lebih mendominasi pembelajaran sedangkan siswa hanya memperhatikan dan mencatat apa yang dijelaskan oleh guru. Guru menjelaskan materi secara bertahap, kemudian memberikan contoh soal, setelah itu memberikan kesempatan kepada siswa untuk bertanya dan merespon kembali apa yang ditanyakan siswa. Namun, jika tidak ada pertanyaan dari siswa maka guru akan melanjutkan materi. Selanjutnya guru memberikan rangkuman dan tugas untuk diselesaikan. Selain itu, selama proses pembelajaran berlangsung hanya siswa-siswa tertentu saja yang memperhatikan, sedangkan siswa yang lainnya tidak memperhatikan apa yang disampaikan guru.

Proses pembelajaran di kedua sekolah berlangsung dengan baik dimana guru dari masing-masing sekolah menerapkan model pembelajaran sesuai dengan langkah-langkah dari model pembelajaran masing- 
masing, namun memberikan hasil akhir yang berbeda juga yang mana sekolah dengan level sedang memperoleh nilai rata-rata tes hasil belajar yang lebih dari sekolah yang level rendah untuk kelas eksperimen maupun kelas kontrol yaitu 66.95148 dan 58.83889 (nilai rata-rata sekolah level sedang) 62.8163 dan 51.79444 (nilai rata-rata sekolah level rendah).

Berdasarkan hasil penelitian sebelumnya yang dilakukan oleh [10] mengenai "Mathematical Learning Outcome Differences Through The Implementation of Cooperative Learning Model of Think Pair Share Type, Two Stay Two Stray Type, and Number Head Together Type”. Hasil penelitiannya menunjukkan bahwa ada perbedaan hasil belajar matematika siswa melalui penerapan model pembelajaran kooperatif tipe think pair share, tipe two stay two stray dan tipe number heads together di Kelas VIII SMP Negeri 1 Palangga. Berdasarkan nilai rata-rata, skor tertinggi pembelajaran matematika siswa adalah kelas eksperimen yang menerapkan model pembelajaran think pair share.

Hal ini senada juga dengan penelitian yang dilakukan oleh [7] mengenai The Differences of Mathematics Learning Outcomes between Think Pair Share (TPS) and Number Heads Together (NHT) menunjukkan bahwa ada perbedaan hasil belajar matematika siswa dengan menggunakan model pembelajaran Think Pair Share(TPS) dan model pembelajaran number heads together. Selanjutnya, hasil belajar matematika siswa dengan menggunakan model pembelajaran Think Pair Share(TPS) lebih baik yaitu 76,55 dari hasil belajar matematika siswa yang menggunakan model pembelajaran number heads together yaitu 55,69.

\section{KESIMPULAN}

Berdasarkan hasil analisis data dan pembahasan hasil penelitian, maka dapat disimpulkan bahwa ada perbedaan kemampuan matematis siswa (hasil belajar) yang diajarkan dengan menggunakan model pembelajaran kooperatif TPS dan model pembelajaran konvensional pada materi lingkaran di kelas VIII SMP ditinjau dari level sekolah. Hal ini ditunjukkan ada hasil perhitungan yang diperoleh, yaitu nilai Sig. (2-tailed) yakni $0,012<0,05$ sehingga menyebabkan $\mathrm{H}_{0}$ ditolak dan $\mathrm{H}_{1}$ diterima yang berarti ada perbedaan kemampuan matematis siswa kelas VIII SMP menggunakan model pembelajaran koopertaif Think Pair Share(TPS) dan model pembelajaran konvensional ditinjau dari level sekolah.

\section{DAFTAR PUSTAKA}

[1] Amalea, I. "Pengaruh Metode Pembelajaran TPS (Think Pair Share) Terhadap Hasil Belajar Matematika," Seminar Nasional Pendidikan Matematika Universitas Indraprasta PGRI, 26 Agustus 2015.

[2] Ayuningtyas, A. D. "Eksperimentasi Model Pembelajaran Kooperatif Tipe Think Pair Share (TPS) Ditinjau Dari Kemandirian Belajar Siswa Kelas VIII SMP Negeri di Kota Yogyakarta," Jurnal Ilmiah Pendidikan Matematika, vol. 3 no. 2, hal. 452-466,Februari 2015.

[3] Fathurrohman, M. Model-Model Pembelajaran Inovatif. Yogyakarta: Ar-Ruzz Media, 2015.

[4] Hartini, Maharani, Rahman. "Penerapan Model Pembelajaran Think-Pair-Share untuk Meningkatkan Kemampuan Komunikasi Matematis Siswa SMP,” Jurnal Matematika Kreatif-Inovatif, vol. 7 no. 2, hal. 131135, Desember 2016.

[5] Huda, M. Cooperative Learning Metode, Teknik, Struktur dan Model Penerapan. Jakarta: Pustaka Pelajar, 2011.

[6] Jatmiko. "Eksperimen Model Pembelajaran Think Pair Share dengan Modul (TPS-M) Terhadap Prestasi Belajar Matematika Ditinjau Dari Minat Belajar,” Jurnal Ilmiah Pendidikan Matematika, vol. 3 no. 2, hal. 417426,Februari 2015.

[7] Kusuma, A. P \& Maskuroh. "The Differences of Mathematics Learning Outcomes between Think Pair Share (TPS) and Number Heads Together (NHT)," Al-Jabar: Jurnal Pendidikan Matematika, vol. 9 no. 1, hal. 19-24, Juni 2018.

[8] Maharani. S, "Eksperimentasi Model Pembelajaran Kooperatif Tipe Group Investigation (GI) dan Think Pair Share (TPS) Pada Materi Sistem Persamaan Linier Ditinjau Dari Sikap Mahasiswa Terhadap Matematika,"Jurnal Ilmiah Pendidikan Matematika, vol. 2 no. 2, hal. 50-57, Februari 2014.

[9] Marta R. "Peningkatan Hasil Belajar Matematika Dengan Model Kooperatif Tipe Think Pair Share Di Sekolah Dasar," Jurnal Cendekia: Jurnal Pendidikan Matematika, vol. 1 no. 2, hal. 74-79, November 2017.

[10] Nur Fitriani dkk. "Mathematical Learning Outcome Differences Through The Implementation Of Cooperative Learning Model Of Think Pair Share Type, Two Stay Two Stray Type, And Number Head Together Type," Jurnal Matematika dan Pembelajaran, vol. 6 no. 2, hal. 199-206, Desember 2018.

[11] Ratumanan, T. G. Inovasi Pembelajaran, Mengembangkan Kompetensi Peserta Didik Secara Optimal. Yogyakarta: Ombak, 2015. 
[12] Sugiyono. Metode Penelitian Pendidikan. Bandung: Alfabeta, 2018.

[13] Trianto. Model-Model Pembelajaran Inovatif Berorientasi Kontruktivistik. Jakarta: Prestasi Pustaka, 2011.

[14] Untari, E. "Eksperimentasi Pembelajaran Kooperatif Tipe STAD Dan TPS Terhadap Prestasi Belajar Matematika Ditinjau Dari Motivasi Berprestasi,” Al-Jabar: Jurnal Pendidikan Matematika, vol. 8 no. 1, hal. 35-42, Juni 2017.

[15] Wijayanto, Z. “Eksperimentasi Model Pembelajaran Kooperatif Tipe Think Pair Share (TPS) Dengan Pendekatan Open-Ended Ditinjau Dari Disposisi Matematis Siswa Kelas VIII SMP Negeri Di Kabupaten Purworejo," Jurnal Ilmiah Pendidikan Matematika, vol 3 no. 2, hal. 427-438, Februari 2015. 
